\title{
Comparative Analysis of the Oil Extracted from Two Different Species of Wild Catfish in Otuocha River, Anambra State, Nigeria
}

\author{
Chigbo, Chidiebere M.*, Lukong, C.B. and Okechukwu, A U. \\ Department of Biochemistry, Faculty of Natural Sciences, Chukwuemeka Odumegwu Ojukwu University, Anambra State, Nigeria. \\ *Corresponding author's email: malachychigbo2010@gmail.com; +2348064398527
}

\begin{abstract}
Catfishes are freshwater fishes of high economic importance in many countries of the world due to their rich source of lipids, protein and other vital nutrients. The present investigation characterizes lipids from two species; Heterobranchus longifillis and Clarias gariepinus of catfishes from Otuocha River, Anambra State, Nigeria. The oils were extracted using soxhlet apparatus and the oil were qualitatively characterized using the standard methods of AOAC and AOCS. The fatty acid profile of the oils were determined using gas chromatography. The results showed that $H$. longifillis had the highest oil composition of $15.33 \pm 0.28 \%$ per 100 g DW followed by $C$. gariepinus $(14.83 \pm 1.61 \%$ per $100 \mathrm{~g} \mathrm{DW})$. The peroxide values of oil extracted from $H$. longifilis was $5.33 \pm 1.51 \mathrm{meq} / \mathrm{kg}$ and $C$. gariepinus, $3.34 \pm 1.51 \mathrm{meq} / \mathrm{kg}$; the acid values for oil extracted from $H$. longifilis was $2.03 \pm$ $0.23 \mathrm{mgKOH} / \mathrm{g}$ and $C$. gariepinus, $1.89 \pm 0.13 \mathrm{mgKOH} / \mathrm{g}$. $p$-anisidine values of $15.38 \pm 0.20$ and $13.57 \pm 0.0 .28$ were obtained for $H$. longifilis and $C$. gariepinus oils respectively while the TOTOX values are $6.12 \pm 0.51$ and $20.99 \pm 1.08$ respectively. Fatty acid profile analysis showed that lauric (12:0), miristric (14:0), palmitic (16:0), stearic $(18: 0)$, oleic $(18: 1)$, linoleic $(18: 9,12)$, and linolenic acids $(18: 6,9,12)$ were dominant in the oils of these fishes. This study has revealed that the qualitative parameters of the extracted oils are within the recommended range by FAO. By having the lowest n-6 PUFA and best quality parameters analysed, $H$. longifilis oil could be regarded as the best oil among the studied species.
\end{abstract}

Original Research Article

Received: $21^{\text {st }}$ Jan., 2018 Accepted: $9^{\text {th }}$ Feb., 2018 Published: $14^{\text {th }}$ Mar., 2018

Keywords: Heterobranchus longifillis Clarias gariepinus Catfish p-anisidine values Fish oil

\section{INTRODUCTION}

Catfishes (Family: Clariidae) are a large group of predominantly freshwater fishes of high economic importance in many countries of the world especially African and Asian continents (Olaniyi and Omitogun, 2014); and also serve mainly as food in many homes and hotels (Omitogun et al., 2012). They also occur in the large rivers such as the Amazon and Zaire (Bruton, 1988). The family Clariidae is divided into two genuses, namely Clarias and Heterobranchus. Madu et al. (1999) reported that two species of Clarias are most popular for fish farming in Nigeria. These are $C$. anguillaris and $C$. gariepinus similarly, only two species of Heterobranchus (H. bidorsalis and H. longifilis) are commonly available (Madu et al., 1999). Recently, there has been an increase in the farming of Catfishes especially Clarias and Heterobranchus species and their hybrids in Nigeria based on their growth performance, short generation interval, and consumer preference or demand, due to their good taste, good flavour, among others (Agbo, 2015; Olaniyi et al., 2017). Consequently, there is a high demand for these catfish seeds by fish farmers for stocking (Olaniyi et al., 2017).

Clarias has a single rayed dorsal fin extending almost to the tail and four pairs of barbels on their flattened, strongly depressed head (Reed et al., 1967). The rayed dorsal fin is continuous, extending to the base of the caudal peduncle. $C$. gariepinus (Fig. 1) has vomer teeth located at the upper jaw which are mostly conical or granular-sub-conical forming a 
crescent band, which may be slightly interrupted in the middle where it is nearly as broad as or narrower than the premaxillary band.

Heterobranchus longifilis (Fig. 2) is a freshwater omnivore which feeds on insects, detritus, benthic invertebrates, tadpoles, shrimps and small fishes (Agbo, 2015). It is characterised by a dorsally flattened broad and bony head with four pairs of barbels and arrayed dorsal fin followed immediately by an adipose fin. The length of the adipose fin varies with the species. $H$. longifills has dorsal and adipose fins equidistance and black spot near to the end of adipose fin. The mouth of this species has no teeth but an abrasive plate, a large buccal cavity and chemosensory barbels which help in locating food (Agbo, 2015).

Fish oil is one of the most important animal lipids and other vital nutrients' sources that are widely consumed by all races and classes of people (Abolude and Abdullahi, 2005). Lipids from fish are well known as a rich source of long-chain n-3 polyunsaturated fatty acids (LC n-3 PUFA) such as eicosapentaenoic acid (EPA) and docosahexaenoic acid (DHA) which cannot be synthesized by humans which are commonly obtained from the diet (Alasalvar et al., 2002). These polyunsaturated fatty acids play crucial roles in various physiological and biochemical processes such as precursors of cellular mediators, maintenance of membrane fluidity, and regulation of enzymes involved in lipid metabolism, and acylation of proteins (Nelson and Cox, 2008). Adequate intake of the essential fatty acids results in numerous health benefits. Documented benefits include prevention of atherosclerosis, reduced incidence of heart disease, stroke and relief from the symptoms associated with ulcerative colitis, menstrual pain and joint pain.

The nutritional quality of food is very important. The nutritional importance of seafood has increased substantially because of the beneficial effects of eating seafood fats and oils (Azam, 2004). The nutritional quality of seafood is affected by body part of the seafood being consumed, method of handling, processing (including cooking at home) season of harvest, sex and species (Krzynowek, 1988). Several methods are used to determine the quality of fish. Physical methods involve the measurement of $\mathrm{pH}$, texture or electrical properties (Chebet, 2010). Chemical methods rely on measurement of metabolite(s) produced during fish storage or distribution, and include among others the acid, peroxide, $p$-anisidine and total oxidation value (TOTOX) (Chebet, 2010). The main purpose of this research work is to determine the acid value, peroxide value, $p$-anisidine value, TOTOX value and the fatty acid composition of the extracted oil from H. longifillis, C. gariepinus and C. gariepinus.

\section{MATERIALS AND METHODS}

\subsection{Sample Collection}

Matured species of wild catfish namely $C$. gariepinus and $H$. longifilis were bought from Otuocha local market close to Otuocha River, Anambra State. The fishes were identified by Mr Vincent Onyeche of National Institute for Freshwater Fisheries Research Bussa, Niger State (Asaba branch).

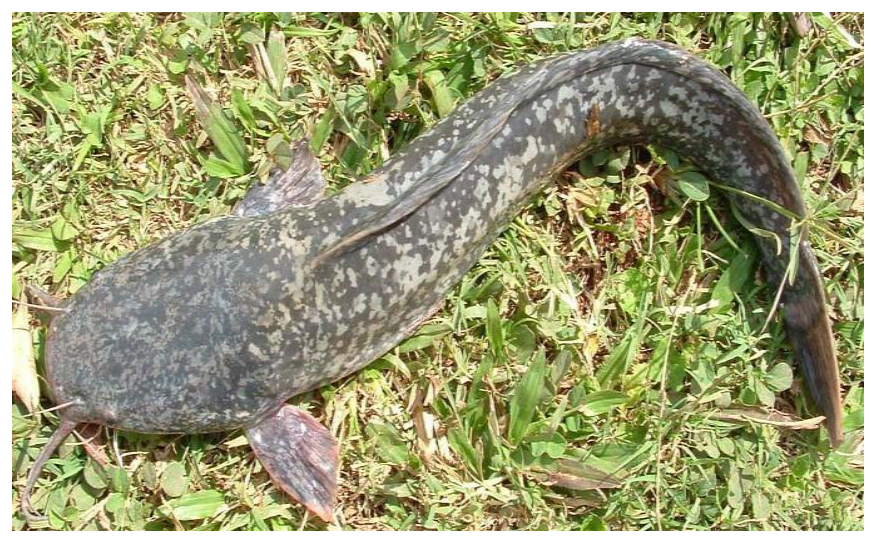

Figure 1: Clarias gariepinus.

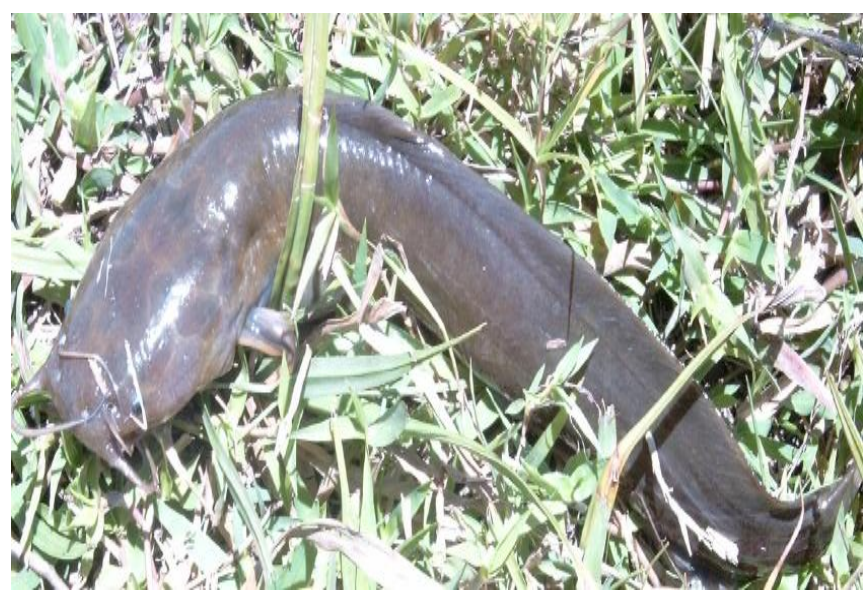

Figure 2: Heterobranchus longifilis.

\subsection{Processing of fish samples}

The fresh fish samples were washed and blotted dry. Individual fresh samples were separated into their anatomical fractions head, bones, flesh and processed using standard methods of the Association of Official Analytical Chemists (AOAC, 1994). The flesh samples were oven dried at $105^{\circ} \mathrm{C}$. Exactly $220 \mathrm{~g}$ of the dried samples were milled into homogenous powder using manual vortex blender. The powdered dried fish sample were stored in airtight container at room temperature. The powdered sample were later used for analyses.

\subsection{Extraction and Crude Lipid Determination}

Exactly $20 \mathrm{~g}$ of the powdered dried fish sample was placed into a pre - weighed extraction thimble $\left(\mathrm{W}_{1}\right)$ and the weight recorded $\left(\mathrm{W}_{2}\right)$. A dry $250 \mathrm{ml}$ round bottom quickfit flask was weighed $\left(\mathrm{W}_{3}\right)$ with a few anti bumping granules inside. The thimble was fitted into the extraction unit of the soxhlet extraction apparatus using a pair of forceps. $300 \mathrm{ml}$ of petroleum ether $\left(40-60{ }^{\circ} \mathrm{C}\right.$ boiling point $)$ was poured into the flask. The apparatus was connected to a condenser. The heating rate was adjusted to give a condensation rate of 2 to 3 drops. After reflux extraction for 4 hours, the thimble was removed and the ether was reclaimed using the apparatus by distilling out some ether. The removal of ether from the flask containing a mixture of ether and extracted fat was completed on a boiling water bath and the flask dried in an oven at 105 
${ }^{\circ} \mathrm{C}$ for 30 minutes. After this, the flask with the pure fat content was cooled in a desiccator and weighed $\left(\mathrm{W}_{4}\right)$.

$$
\% \text { Crude fat }=\frac{W_{4}-W_{3}}{W_{2}-W_{1}} \times 100
$$

Where $\mathrm{W}_{1}$ is weight extraction thimble; $\mathrm{W}_{2}$ is weight of fish sample and extraction thimble; $\mathrm{W}_{3}$ is weight of round bottom flask and $\mathrm{W}_{4}$ is weight of round bottom flask and extracted oil

\subsection{Methods involved in the Qualitative Characterization of Extracted Oil Samples}

\subsubsection{Determination of Acid Value}

The acid value of the oil sample was determined according to the procedure described in the AOCS official methods (AOCS, 1989). Exactly $125 \mathrm{ml}$ of 1:1 toluene-isopropyl alcohol and $2 \mathrm{ml}$ of phenolphthalein indicator were placed into a $250 \mathrm{ml}$ Erlenmeyer flask and neutralized by with $0.1 \mathrm{~N}$ potassium hydroxide to a faint but permanent pink color $\left(1^{\text {st }}\right.$ titration). In another Erlenmeyer flask, $2.5 \mathrm{~g}$ of the extracted oil sample was weighed and $125 \mathrm{ml}$ of 1:1 toluene-isopropyl alcohol and $2 \mathrm{ml}$ of phenolphthalein indicator was added to the oil sample and mixed thoroughly. Titration was then carried-out with $0.1 \mathrm{~N}$ potassium hydroxide to permanent pink color ( $2^{\text {nd }}$ titration). The acid value $(\mathrm{g} \mathrm{KOH} / \mathrm{kg}$ of sample) was calculated.

$$
\text { Acid value }=\frac{(A-B) \times N \times 56.1}{W}
$$

Where $\mathrm{A}$ is the volume of standard $\mathrm{KOH}$ used in titrating the oil sample in $\mathrm{ml}$; $\mathrm{B}$ is the volume of standard $\mathrm{KOH}$ used in titrating the blank $\left(1^{\text {st }}\right.$ titration $) ; \mathrm{N}$ is the normality of standard $\mathrm{KOH}$; W is the weight in grams of oil sample and 56.1 is the molecular weight of $\mathrm{KOH}$.

\subsubsection{Determination of Peroxide Value}

The peroxide value of the oil samples was determined using the procedure described in AOCS official method (AOCS, 1989). Exactly $5 \mathrm{~g}$ of oil sample was placed in a $250 \mathrm{ml}$ Erlenmeyer flask. Then $30 \mathrm{ml}$ of $3: 2$ acetic aciddichloromethane were added and the flask was swirled to dissolve the sample. $0.5 \mathrm{ml}$ potassium iodide solution was added and the solution was allowed to stand for $1 \mathrm{~min}$. this was followed by the addition of $30 \mathrm{ml}$ of distilled water. This mixture was titrated against $0.1 \mathrm{~N}$ sodium thiosulfate until the yellow color disappeared. About $0.5 \mathrm{ml}$ of starch indicator solution was added and the titration continued with constant agitation till the blue color disappeared. A blank was prepared without adding the oil sample. The peroxide value was calculated.

$$
\text { Perioxide Value }=\frac{(S-B) \times N \times 1000}{W}
$$

Where $\mathrm{S}$ is the volume of titrated oil sample (ml); B is the volume of titrated blank $(\mathrm{ml}) ; \mathrm{N}$ is the normality of sodium thiosulfate solution and $\mathrm{W}$ is the weight of oil sample (in gram).

\subsubsection{Determination of $\boldsymbol{P}$-Anisidine Value}

The $p$-Anisidine value of oil sample was determined using the procedure described in the AOCS official method (AOCS, 1989). Exactly $1 \mathrm{~g}$ of oil was placed into a $25 \mathrm{ml}$ volumetric flask. It was dissolved in iso-octane and diluted to $25 \mathrm{ml}$ with iso-octane (fat solution). The absorbance of the fat solution was read at $350 \mathrm{~nm}$ in a $3 \mathrm{ml}$ glass cuvette with a Cam 253 series spectrophotometer against pure iso-octane. Pipette $5 \mathrm{ml}$ of the fat solution into a test tube A and $5 \mathrm{ml}$ of iso-octane into a test tube $\mathrm{B}$. Add $1 \mathrm{ml}$ of $p$-anisidine reagent into test-tubes A and B. Both tubes were thoroughly shaked. After 10 minutes, their absorbance was read at $350 \mathrm{~nm}$.

$$
p-\text { anisidine value }=\frac{25\left(1.2 A_{S}-A_{B}\right)}{W}
$$

Where $A_{S}$ is the net Absorbance of the fat solution after reaction with the $p$-anisidine reagent; $A_{B}$ is the net Absorbance of the fat solution; $\mathrm{W}$ is the weight of oil $(\mathrm{g}) ; 25$ is the size of volumetric flask used and 1.2 is the correction factor.

\subsubsection{Determination of TOTOX Value}

TOTOX means "Total Oxidation", calculated as twice the Peroxide value (PV) plus Anisidine value (AV).

$$
\text { TOTOX value }=2 \mathrm{PV}+\mathrm{AV}
$$

\subsection{Fatty Acid Profile Analysis}

Exactly $1 \mathrm{ml}$ of oil sample was dissolved in $50 \mathrm{ml}$ of chloroform and transferred to a $100 \mathrm{ml}$ volumetric flask. After which $1 \mathrm{ml}$ of Hilditch reagent was added and the reaction mixture was then sealed and placed in a water bath for 30 minutes at $40^{\circ} \mathrm{C}$. This was followed by extracting $1 \mathrm{ml}$ from the reaction mixture, and was then mixed with $1 \mathrm{ml}$ of hexane and $1 \mathrm{ml}$ of water. The mixture was shaken vigorously for 2 minutes. When a stable emulsion was formed it was then centrifuge at $4000 \mathrm{rpm}$ for 10 minutes at $25{ }^{\circ} \mathrm{C}$. Half of the top hexane phase was transferred to a small test tube for injection into gas chromatographic chamber for analysis. Fatty acid analyses were carried out using the Association of Official Analytical Chemist method (AOAC, 1990).

Fatty acids of the fishes were analyzed with a Buck 530 gas chromatograph equipped with capillary column SP-2330 and a flame ionization detector (FID). Separation of fatty acid methyl esters was achieved by using fused silica capillary columns (30 m x $0.25 \mathrm{~mm} \times 0.20 \mu \mathrm{m}$ film thickness). The oven temperature was set at $120^{\circ} \mathrm{C}$ for 2 minutes then raised to $220^{\circ} \mathrm{C}$ with a ramp rate of $5{ }^{\circ} \mathrm{C} / \mathrm{min}$, and then held for 15 minutes. The injector and detector temperatures were maintained at $240{ }^{\circ} \mathrm{C}$ and $250{ }^{\circ} \mathrm{C}$, respectively. The carrier gas was helium 10 psi with a split ratio of $1 / 50$. The air and hydrogen pressure were $338 \mathrm{ml} / \mathrm{min}$ and $45 \mathrm{ml} / \mathrm{min}$ respectively. Results were expressed as the percentage of each fatty acid with respect to the total fatty acids. 


\subsection{Statistical analysis}

The mean value and standard error mean were calculated from the result obtained from the three samples for each specie. All statistics were performed using SPSS 2.2 version 1 for Windows (SPSS Inc., Chicago, IL. USA).

\section{RESULTS}

The percentage oil yield of the two different species of catfish is presented in Table 1 as mean \pm standard deviations of triplicate determinations. $H$. longifillis had the highest oil composition of $15.38 \% / 100 \mathrm{~g}$ dry weight (DW).

The results obtained from the qualitative characterization of extracted oil samples were presented as mean \pm standard deviation of triplicate determinations in Table 2. H. longifilis oil has an acid value of $2.03 \pm 0.23 \mathrm{mgKOH} / \mathrm{g}$ and $C$. gariepinus had the least value $(1.89 \pm 0.12 \mathrm{mgKOH} / \mathrm{g})$. The recommended range by FAO for acid value is $\leq 3 \mathrm{mg} \mathrm{KOH} / \mathrm{g}$. From the results, the oil extracted from $C$. gariepinus had the lowest peroxide value of $3.33 \pm 1.15 \mathrm{meq} / \mathrm{kg}$ while the oil extracted from $H$. longifilis had the peroxide value of $5.33 \pm 1.15 \mathrm{meq} / \mathrm{kg}$. The recommended range by FAO for perioxide value is $5 \geq \mathrm{meq} / \mathrm{kg}$. The $p$-anisidine determination indicated that $H$. longifilis had the highest $p$ - anisidine value of $15.38 \pm 0.20$ followed by $C$. gariepinus oil with $p$ - anisidine value of $13.58 \pm 0.28$. The recommended range by FAO for $\mathrm{p}-$ anisidine value is $\leq 20$. While $H$. longifilis had the highest TOTOX value $(26.12 \pm 0.51)$. The recommended range by FAO for TOTOX value is $\leq 26$.

Table 1: Percentage Oil Yield of Oils Extracted from $C$. gariepinus and H. longifilis.

\begin{tabular}{ll}
\hline Species & $\begin{array}{l}\text { (\%) Oil Yield per 100 g dry } \\
\text { weight }\end{array}$ \\
\hline H. longifilis & $15.33 \pm 0.26$ \\
C. gariepinus & $14.83 \pm 1.61$ \\
\hline
\end{tabular}

Table 2: Qualitative Characterization of Extracted Oil Samples.

\begin{tabular}{lllll}
\hline Species & $\begin{array}{l}\text { Acid value } \\
\text { (mgKOH/g) }\end{array}$ & $\begin{array}{l}\text { Peroxide value } \\
(\mathbf{m e q} / \mathbf{k g})\end{array}$ & $\begin{array}{l}\boldsymbol{p} \text {-anisidine } \\
\text { value }\end{array}$ & $\begin{array}{l}\text { TOTOX } \\
\text { value }\end{array}$ \\
\hline H. longifilis & $2.03 \pm 0.23$ & $5.33 \pm 1.15$ & $15.38 \pm 0.20$ & $26.12 \pm 0.51$ \\
C. & $1.89 \pm 0.12$ & & & $20.99 \pm 1.08$ \\
gariepinus & & $3.33 \pm 1.15$ & $13.58 \pm 0.28$ & \\
\hline
\end{tabular}

The results of the fatty acid profile of $C$. gariepinus oil was presented in Table 3. Six fatty acid methyl ester mixtures were identified in oil extracted from $C$. gariepinus. Only one was a polyunsaturated fatty acid (C18:2 ${ }^{\Delta 9,12}$ Linoleic Acid) while the rest were saturated fatty acids. Miristic Acid had the highest concentration (17.63\%) among the saturated fatty acids as shown in Table 3.

Table 3: Fatty Acid Profile of oil extracted from $C$. gariepinus.

\begin{tabular}{ll}
\hline Fatty acids & \% Concentration \\
\hline Saturated Fatty Acid & \\
C12:0 (Lauric Acid) & 5.08 \\
C14:0 (Miristic Acid) & 17.63 \\
C17:0 (Heptadeconoic Acid) & 1.73 \\
C18:0(Stearic Acid) & 5.69 \\
C20:0 (Arachidic Acid) & 1.12 \\
Polyunsaturated Fatty Acid & \\
C18:2 & \\
\hline
\end{tabular}

The results of the fatty acid profile of $H$. longifilis oil was presented in Table 4. Six fatty acids were detected in $H$. longifilis. Out of which two were unsaturated (Oleic Acid and
Linolenic Acid) while others were saturated fatty acids. Among the saturated fatty acids, palmitic acid had the highest concentration $(21.04 \%)$. Linolenic Acid had the highest concentration of $60.17 \%$ among all the fatty acids identified (Table 4)

Table 4: Fatty Acid Profile of oil extracted from $H$. longifilis.

\begin{tabular}{ll}
\hline Fatty acids & \% Concentration \\
\hline Saturated Fatty acids & \\
C12:0 (Lauric Acid) & 11.65 \\
C14:0 (Miristic acid) & 6.07 \\
C16:0 (Palmitic Acid) & 21.04 \\
C18:0 (Stearic acid) & 1.05 \\
$\begin{array}{l}\text { Monounsaturated Fatty acid } \\
\text { C18:1 }{ }^{\Delta 9} \text { (Oleic Acid) }\end{array}$ & 0.02 \\
$\begin{array}{l}\text { Polyunsaturated Fatty acid } \\
\text { C18:2 }\end{array}$ & \\
\hline
\end{tabular}

Table 5 is a presentation of the comparative analysis of the fatty acids present in the oils extracted from $H$. longifilis and C. gariepinus fatty acids composition. 
Table 5: A Comparative Analysis of the fatty acids present in H. longifilis and C. gariepinus.

\begin{tabular}{lllllll}
\hline Oil Fatty Samples & $\begin{array}{l}\text { Total } \\
(\boldsymbol{\%})\end{array}$ & SFA & $\begin{array}{l}\text { Total } \\
(\boldsymbol{\%})\end{array}$ & $\begin{array}{l}\text { Total MUFA } \\
(\boldsymbol{\%})\end{array}$ & PUFA/SFA & $\begin{array}{l}\text { n-6 } \\
(\boldsymbol{\%})\end{array}$ \\
\hline H. longifilis. & 39.81 & 60.17 & 0.02 & 1.50 & 60.17 \\
C. gariepinus & 31.25 & 68.75 & 0.00 & 2.20 & 68.75 \\
\hline
\end{tabular}

Saturated Fatty Acids = SFA, Polyunsaturated Fatty Acids = PUFA, Monounsaturated Fatty Acids = MUFA.

\section{DISCUSSION}

The characterization of fish oil is important as it helps in checking the quality of the oil and its nutritional value. In the present study, the oil extracted from the two catfish species were characterized based on peroxide value, acid value, $p$ anisidine value, TOTOX value and fatty acid profile. From Table $1, H$. longifillis had the highest oil composition of $15.33 \pm 0.28 \% / 100 \mathrm{~g} \mathrm{DW}$ which is slightly higher than the fillets of $C$. gariepinus which had oil composition of $14.83 \pm 1.61 \% / 100 \mathrm{~g}$ DW respectively. These individual differences may be explained by the nutritional status of each individual. However, the individual differences in catfish fillets are very surprising since they all have the same access to food. Explanations could be hierarchy or differences in appetite or effects of environmental conditions. For example, Okonji et al. (2015) found that farmed $C$. gariepinus fed with commercial diet (coppens) from the Faculty of agriculture, department of fisheries experimental tanks, University of Benin Benin-city, Edo state, Nigeria and wild C. gariepinus from Ikpoba River, Benin-city, Edo state, Nigeria had a fat content of $6.543 \%$ and $5.82 \%$, respectively. The high lipid contents of the studied fishes make them good sources of oil when compared to other fishes, even farmed fish.

The peroxide values obtained indicates that $H$. longifilis and C. gariepinus has $5.33 \pm 1.15 \mathrm{Meq} / \mathrm{kg}$ and $3.33 \pm 1.15 \mathrm{Meq} / \mathrm{kg}$ respectively. The peroxide value represents the number that expresses in milliequivalents of active oxygen the quantity of peroxide contained in $1000 \mathrm{~g}$ of the substance (European Pharmacopoeia, 2005). The number of peroxides present in the oil is an index of their primary oxidative level and its tendency to go rancid. The lower the peroxide value the better the oil quality and its state of preservation (CDR, 2008). The recommended range of peroxide value by FAO for peroxide value is $\leq 5 \mathrm{meq} / \mathrm{kg}$ (FAO, 2008). Peroxide values obtained for both extracted oil are below the recommended limit. $H$. longifilis oil can be seen as the best fish.

The results obtained for the acid values for $H$. longifilis and C. gariepinus are $2.03 \pm 0.23 \mathrm{gKOH} / \mathrm{kg}$ and $1.89 \pm 0.12$ $\mathrm{gKOH} / \mathrm{kg}$ respectively. The acid value is important because it is still a reliable parameter for oil quality (FAO, 1986). The recommended range of acid value is $<3 \mathrm{gKOH} / \mathrm{kg}$ (FAO, 2012). The present results corroborate with the findings of Islam et al. (2013) who reported a lower acid value of 1.93 $\mathrm{mg} \mathrm{KOH} / \mathrm{g}$ for a wild species of Clarias (Clarias batrachus) from Bangladesh and differs with Abdulkadir et al. (2010) who reported that the acids value of oil obtained from wild C. angullaris from Minna Niger State, Nigeria, was $5.04 \mathrm{mg}$ $\mathrm{KOH} / \mathrm{g}$. The lower acid values of the studied fishes is an indication that they can be stored for a long time.

The non-volatile secondary oxidation end-products are measured by $p$-anisidine value. The $p$-anisidine value is usually associated with the term oxidative rancidity which is an indicator of the level of off-flavour and off-odours (St. Angelo, 1996). The results from the present study indicated that the anisidine values of $H$. longifilis and $C$. gariepinus are $15.38 \pm 0.20$ and $13.58 \pm 0.28$ respectively. The values are within the recommended allowable limit of $\leq 20$ set by FAO for quality and acceptability of fish oils for human consumption. However, $H$. longifilis has the highest $p$ anisidine value, $15.38 \pm 0.20$ probably due to higher composition of PUFA than $C$. gariepinus which may cause the oil to undergo secondary oxidation faster.

The total oxidation value (TOTOX) is a quality parameter used to determine the presence of various compounds such as hydroperoxides, aldehydes and ketones which are generated by degradation of polyunsaturated fatty acids under prooxidant conditions including high temperatures, oxygen, metallic compounds and light (Rubio-Rodriguez, 2012). The results from the present study indicated that $H$. longifilis and C. gariepinus had the TOTOX values of $26.04 \pm 2.50$ and $20.24 \pm 2.28$ respectively. The values are within the recommended and the allowable limit of $\leq 26$ set by FAO for quality and acceptability of fish oils for human consumption. Among the studied fish, $H$. longifilis had the highest TOTOX value. This could be due to high level of unsaturation of its fatty acids.

Dominant fatty acids in oils extracted from the studied fishes are lauric acid (12:0), miristic acid (14:0), palmitic acid (16:0), stearic acid (18:0), oleic acid (18:1), linoleic acid $(18: 9,12)$, and linolenic acid $(18: 6,9,12)$ (Table 3-5). These fatty acids $(16: 0 ; 18: 0 ; 16: 1 ; 18: 1)$ are preferred substrates for mitochondrial $\beta$-oxidation and heavily catabolized via the TCA cycle to generate metabolic energy in fish (Henderson and Sargent, 1985). This is related with the results of Okonji et al., (2015) who identified six fatty acids: Palmitic (28.14 $\mathrm{g} / 100 \mathrm{~g}$ ), Linoleic (23.48 g/100g), Oleic (21.40 g/100g), Stearic (15.44 g/100g), Linolenic (10.28 g/100g), and Behenic $(0.85 \mathrm{~g} / 100 \mathrm{~g})$ in wild catfish from Ikpoba River, Benin-city, Edo state, Nigeria. In H. longifilis, unsaturated fatty acid $(60.19 \%)$ were more than saturated fatty acid $(39.81 \%)$ and polyunsaturated fatty acids $(60.17 \%)$ were more than monounsaturated fatty acid (0.02). In $C$. gariepinus, the polyunsaturated fatty acids $(68.75 \%)$ were more than saturated fatty acids (31.25\%) and monounsaturated fatty acids was not found. Also, the high percentage of unsaturated fatty acid could be attributed to their natural habitat as organisms synthesize or accumulate polyunsaturated fatty acids to ensure membrane fluidity at reduced temperatures (Nelson and Cox, 2008). Zenebe et al. (1998) have argued that variation in tissue lipid and fatty acid in herbivorous fish is greater than in those of carnivore fish and is due to the diversity of food habit. H. longifilis is a freshwater omnivore which feeds on insects, detritus, benthic invertebrates, tadpoles, shrimps and small fishes while $C$. gariepinus is an herbivore (Agbo, 2015). 
All the PUFA identified in all the fishes are of n-6 PUFA (polyunsaturated fatty acids) (Table 5). This finding agrees with Ugoala (2008) who reported that n-6 PUFAs are the dominant PUFA in some freshwater fishes. The n-6 derivatives are stronger and tends to trigger of inflammation, which underlies conditions such as atherosclerosis (Pratt and Cornely, 2014). However, the relative amounts of n-3 and n6 fatty acids might therefore matter more than the absolute amount of n-3 fatty acids consumed (Pratt and Cornely, 2014). Thus, the fishes should be consumed with caution. The palmitic, lauric acid, mistric acid and stearic acid were the major types of saturated fatty acids found in the studied fish groups (Table 3-5). Miristic acid was highest in $C$. gariepinus. This finding is similar to the report of (Ollis et al, 1999; Okonji et al., 2015) who reported mistric acid as the dominant saturated fatty acid in wild $C$. gariepinus. Palmitic acid were highest in $H$. longifilis. A common constituents in liver is palmitoleic acid. It is biosynthesized from palmitic acid (C16:0) which is found in considerable amounts in $H$. longifilis. Fish having energy depots in the form of lipids will rely on this palmitoleic acid. It is a beneficial fatty acid which when consumed increases insulin sensitivity by suppressing inflammation and inhibits the destruction of pancreatic betacells which are known to secrete insulin (Dutta and Dutta, 2013). These existing interspecies variability in the composition of fatty acid of fish lipids (and of the specific PUFA in particular) can be explained by the existence of a large number of external factors (environment, tropic effects) and internal factors (fish species, feeding regime and digestion, life cycle, stage, composition of lipids triglycerols, phospholipids and their topographical origin) (Ashim et al., 2014).

Food with polyunsaturated and saturated fatty acids ratio (PUFA/SFA) below 0.45 have been considered as undesirable by the Department of Health and Social Security, United Kingdom (1984); this ratio coincide with recommendation by Enser et al (1998) based on information from the English Health Department, United Kingdom: foods with ratio under 0.45 have the potential to raise blood cholesterol levels. In this study, the ratio of PUFA/SFA was 2.20 for $C$. gariepinus and 1.50 for $H$. longifilis. These values are higher than the value $(0.45)$ as recommended by the Department of Health and Social Security, UK. This is an indication that the oils from both species of fishes are would be beneficial to the body when consumed.

\section{CONCLUSION}

The present study has indicated that the studied catfish oil are of high quality as all the quality parameters analysed are within the recommended range of FAO. Also, they are all nutritionally important in terms of PUFA/SFA ratio as all the catfish species had high content of PUFA/SFA ratio. However, C. gariepinus oil could be regarded as the best by having the highest PUFA/SFA ratio of 2.2 , and best quality parameters analysed.

\section{REFERENCES}

Abdulkadir, M., Abubakar, G. I. and Mohammed, A. (2010) Production and characterization of oil from fishes. J. Engi. Appl. Sci. 5(7): 555-559
Abolude, D. S, and Abdullahi, S. A. (2005). Proximate and mineral contents in component parts of Clarias gariepinus and Synodontis schall from Zaria, Nigeria. Nig. Food J. 23:1- 8 .

Agbo, A. N. (2015) Evaluation of Leucaena leucocephala (Lam De Wit) Leafmeal. In The Diet of Heterobranchus Longifilis Valenciennes. Unpublished Thesis for the Award of Doctor of Science at Ahmadu Bello University, Zaria, Nigeria, pp.34-36.

Alasalvar, C. Taylor, K.D., Zubcov, E., Shahidi, F. and Alexis, M. (2002). Differentiation of cultured and wild sea bass (Dicentrarchus labrax): total lipid content, fatty acid and trace mineral composition. Food Chem; 79:145 150 .

AOAC (1994). Official Methods of Analysis of the Association of Official Analytical Chemist. $17^{\text {th }}$ (ed). International Maryland USA. 77(4):25-31

AOAC. (1990). Official methods of analysis of the Association of Official Analytical Chemists $5^{\text {th }}$ (ed). Arlington, V.A. U.S.A. pp 2217-2280

Ashim, K. N., Anindita, P., Babita, S., Debalina, D., Ipsita, D., Ipsita, M., Nabanita, G. and Soumi P. (2014).Fatty acid compositions of four edible fishes of Hooghly Estuary, West Bengal, India. Int. J. Curr. Microbiol. App. Sci 3(7): 208-218

Azam, K. and Ali, M.Y. (2004). Biochemical Assessment on Selected Fresh Fish, J. Biol. Sci., 4(1): 9-10.

Bruton, M. N. (1988). "Systematics and biology of Clariid catfish" In: Hecht, T., Uys, W. and Britz, P. J (eds). The culture of sharptooth catfish, Clarias gariepinus in South Africa National Scientific Programmes Report No. 153 pp 1

CDR. (2008). Determination of Peroxide Value in Oils and Fats. (Retrieved on Feb 13th 2011) http://www.cdr-mediared.com/fooddiagnostics/chemical-test-food/peroxides-oils-fats

Chebet, L. (2010). Methods for Evaluation of fish freshness and quality. Retrieved on $10 / 05 / 2017$ from www.skemman.is/.../Masters_thesis_2010_Lilli...

Department of Health and Social Security. (1984). Diet and cardiovascular disease. Report on Health and Social Subjects 28. London, UK. p 1

Dutta, M and Dutta, P. (2013). A study of the fatty acid profile in muscle of Monopterus chuchia. Oriental J. of Chem. 29(4): 1501-1505.

Enser, M., Hallet, K. G., Fursey, G. A. J., Wood, J. D., and Harrington, G. (1998). Fatty acid content and composition of UK beef and lamb muscle in relation to production system and implications for human nutrition. Meat Sci., 49: 329-341

European Pharmacopoeia. (2005). Peroxide value. (Retrived on September 28/2012).

http://lib.njutcm.edu.cn/yaodian/ep/EP5.0/02_methods_of_analysis/2.5.__a ssays/2.5.5.\%20Peroxide\%20value.pdf.

FAO (1986). The production of fish meal and oil. Fisheries Technical PaperT142. Fisheries Industries Division.p 63.

FAO (2005). "Post-harvest changes in fish" In: FAO fisheries and aquaculture department, Food Rome, Italy, (Retrieved on 2nd March, 2010) and Agriculture Organization,

FAO (2005). Regional Review on Aquaculture Development in SubSahara Africa. FAO Fisheries Circular No. 1017/4 pp 1-23.

FAO. (2008) Fats and Fatty Acids In: Human Nutrition Report of An Expert Consultation Food And Nutrition Paper Geneva pp. 91-97.

Henderson, R.J. (1996). Fatty acid metabolism in freshwater fish with particular reference to polyunsaturated fatty acids. Archive fur Tierenahr 49: $5-22$ 
Islam, R., Mondol, L.K., Sheikh, L., Rahman, S.S., Islam, M. and Rahman, A. (2013).Identification of fatty acid profile,lipid characterization and nutritional status of Clarias batrachus. Nutr Sci Food Technol. 1:1

Krzynowek, J. (1988). "Effects of Handling, Processing and Stor- age of Fish and Shellfish," In: E. Karmas and R. S. Harris, Eds., Nutritional Evaluation of Food Processing, 3rd Edi- tion, Van Nostrand Reinhold, New York, pp. 245- 265.

Madu, C.T., Ita, E.O. and Mohammed, S. (1999). Fishy Business. African Farming. pp. 11-14.

Nelson, D.L and Cox, M.M. (2008). Lehninger Principles of Biochemistry; $5^{\text {th }}$ edition. W.H. Freeman and Company. New York, USA pp. 1119

Okonji, V. A., Omogwu, J. N. and Ihenyen, E. H. (2015). Lipid and fatty acid composition of pond raised and wild Oreochromis niloticus and Clarias gariepins NJAFE, 11(1):19-22

Olaniyi, W. A., and Omitogun, O.G. (2013). Stages in the early and larval development of the African catfish Clarias gariepinus (Teleostei, Clariidae). Zygote 22:314-330.

Olaniyi, W. A., and Omitogun, O.G. (2014). Embryonic and larval developmental stages of African giant catfish Heterobranchus bidorsalis (Geoffroy Saint Hilaire, 1809) (Teleostei, Clariidae). Springer Plus 3: 677.

Olaniyi, W. A., Makinde, O. A. and Omitogun, O. G. (2017).Comparison of proximate composition and sensory attributes of Clariid catfish species of Clarias gariepinus, Heterobranchus bidorsalis, and their hybrids. Food Sci. Nutr.. 5(2):285-291

\section{$\underline{\text { How to cite this article }}$}

Chigbo, C.M., Lukong, C.B. and Okechukwu, A U. (2018). Comparative Analysis of the Oil Extracted from Two Different Species of Wild Catfish in Otuocha River, Anambra State, Nigeria. Tropical Journal of Applied Natural Sciences, 2(2): 78-84. Doi: https://doi.org/10.25240/TJANS.2018.2.2.11.
Ollis, T. E., Meyer, B. J. and Howe, P. R. (1999). Australian food sources and intake of omega- 6 and omega-3 polyunsaturated fatty acids. Ann. Nutr. Metab 43: 346-355

Omitogun, O. G., Ilori, O., Olaniyan, O., Amupitan, P., Oresanya, T. and Aladele, S. (2012). "Cryopreservation of the sperm of the African catfish for the thriving aquaculture industry in Nigeria" in: I. Katkov, (ed.). In: I Current frontiers in cryopreservation 2: 305-329. Intech Publishers, Croatia.

Pratt, C.W. and Cornely, K. (2014). Essential Biochemistry. $3^{\text {rd }}$ edition. John Wiley and Sons, Inc, USA. pp. 627

Reed, W., John, B., Hopson, A.J., Jonathan, J. and Yaro, I. (1967). Fish and fisheries of Northern Nigeria. First Edition. Ministry of Agriculture Northern Nigeria. pp. 226

Rubio-Rodríguez, N., de Diego, S.M., Beltrán, S., Jaime, I., Sanz, M.T. and Rovira, J. (2008). Supercritical fluid extraction of the omega-3 rich oil contained in hake (Merluccius capensis-Merluccius paradoxus) byproducts: study of the influence of process parameters on the extraction yield and oil quality. J. Supercritical Fluids, 47: 215-226.

Sargent, J. R. (1996). “Origins and functions of egg lipid” In: N. R. Bromage and R. J. Roberts (eds.), Broodstockmanagement and egg and larval quality.Blackwell,Oxford pp. 353-372.

St. Angelo, A.J. (1996). Lipid oxidation in foods. Critical reviews. Food Sci. Nutri., 36: 175-224.

Ugoala, E (2008) Investigation of the Component Fatty Acids of Some Freshwater Fishes Common In: Nigeria And A Comparative Study Of Their Nutritional Quality With Those Of Marine. M Sc Thesis submitted to Department Of Chemistry, Faculty of Science, Ahmadu Bello University, Zaria Nigeria. pp. 56. 